Article

\title{
Development of a Simple DNA Extraction Method and Candida Pan Loop-Mediated Isothermal Amplification Assay for Diagnosis of Candidemia
}

\author{
Da Hye Lim ${ }^{1,+}{ }^{\dagger}$ Hyunseul Jee ${ }^{2,+}$, Kyung Chul Moon ${ }^{3}$, Chae Seung Lim ${ }^{1}\left(\mathbb{D}\right.$ and Woong Sik Jang ${ }^{3, * \mathbb{C}}$ \\ 1 Departments of Laboratory Medicine, College of Medicine, Korea University Guro Hospital, \\ Seoul 08308, Korea; 1dh9692@korea.ac.kr (D.H.L.); malarim@korea.ac.kr (C.S.L.) \\ 2 BK21 Graduate Program, Department of Biomedical Sciences, College of Medicine, Korea University, \\ Seoul 08308, Korea; jhs603@korea.ac.kr \\ 3 Emergency Medicine, College of Medicine, Korea University Guro Hospital, Seoul 08308, Korea; \\ cmooner@korea.ac.kr \\ * Correspondence: plasmid18@korea.ac.kr; Tel.: +82-2-2626-3245 \\ + These authors contributed equally to this work.
}

check for updates

Citation: Lim, D.H.; Jee, H.; Moon,

K.C.; Lim, C.S.; Jang, W.S.

Development of a Simple DNA

Extraction Method and Candida Pan

Loop-Mediated Isothermal

Amplification Assay for Diagnosis of

Candidemia. Pathogens 2022, 11, 111.

https://doi.org/10.3390/

pathogens11020111

Academic Editor: Ching-Chi Lee

Received: 31 December 2021

Accepted: 17 January 2022

Published: 18 January 2022

Publisher's Note: MDPI stays neutral with regard to jurisdictional claims in published maps and institutional affiliations.

Copyright: () 2022 by the authors Licensee MDPI, Basel, Switzerland. This article is an open access article distributed under the terms and conditions of the Creative Commons Attribution (CC BY) license (https:// creativecommons.org/licenses/by/ $4.0 /)$.

\begin{abstract}
To reduce the morbidity and mortality of candidemia patients through rapid treatment, the development of a simple, rapid molecular diagnostic method that is based on nucleic acid extraction and is superior to conventional methods for detecting Candida in the blood is necessary. We developed a multiplex Candida Pan/internal control (IC) loop-mediated isothermal amplification (LAMP) assay and a simple DNA extraction boiling protocol using Chelex-100 that could extract yeast DNA in blood within $20 \mathrm{~min}$. The Chelex-100/boiling method for DNA extraction showed comparable efficiency to that of the commercial QIAamp UCP Pathogen Mini Kit using Candida albicans qPCR. In addition, the Candida Pan/IC LAMP assay showed superior sensitivity to that of general Candida Pan and species qPCRs against clinical DNA samples extracted with the QIAamp UCP Pathogen Mini Kit and Chelex-100/boiling method. The Candida Pan/IC LAMP assay followed by Chelex-100/boilingmediated DNA extraction showed high sensitivity (100\%) and specificity (100\%) against clinical samples infected with Candida. These results suggest that the Candida Pan/IC LAMP assay could be used as a rapid molecular diagnostic test for candidemia.
\end{abstract}

Keywords: Candida spp.; Candida albicans; DNA extraction; Chelex-100; multiplex LAMP

\section{Introduction}

Candida species are among the top five infectious bloodstream pathogens and remain the most common cause of invasive fungal infections [1]. Invasive candidiasis, which occurs when Candida spp. infect other tissues and organs, infects more than 250,000 people worldwide each year and causes more than 50,000 deaths [2,3]. The reported candidemia mortality ranges from $30 \%$ to $60 \%$ with up to 30 days of increase in the length of hospital stay for survivors [4].

Early diagnosis is critical for appropriate patient management and for improving the outcomes of candidemia. Blood cultures, the current diagnostic gold standard, are limited by low sensitivity, ranging from $21 \%$ to $71 \%$ [5], and a slow turnaround, usually exceeding $48 \mathrm{~h}$ [6-8]. Therefore, various non-culture-based diagnostic methods such as immunoassay (mannan, anti-mannan antibodies and (1-3)- $\beta$-d-glucan (BDG) assay) [9-11] and PCR [8] have been developed; however, detection methods using mannan, anti-mannan antibodies and BDG have been reported to have low specificity [10,12] and PCR-based diagnosis is time-consuming, although the detection specificity is high. Therefore, the development of a fast diagnosis system is required for the detection of fungi in blood. 
Recently, several isothermal amplification techniques for Candida have been proposed as molecular diagnostic methods to overcome these limitations, including loopmediated isothermal amplification (LAMP) [13], nucleic acid sequence-based amplification (NASBA) [14] and rolling circle amplification [15]. Among these isothermal amplification methods, LAMP is the most extensively investigated method for Candida detection $[13,16,17]$. Inàcio et al. reported a LAMP technique for the amplification of the $26 \mathrm{~S}$ rRNA gene in clinically relevant Candida yeasts [13]. Fallahi et al. developed a C. albicans-specific LAMP assay using fluorescence detection [16]. Hongling et al. established multiple pathogen loop-mediated isothermal amplification (LAMP) using microfluidic chip technology for Staphylococcus aureus, Escherichia coli, Pneumoniae Klebsiella, Shigella, methicillin-resistant Staphylococcus aureus (MRSA) and C. albicans [17]. LAMP is composed of six primers, of which four primers contain six parts of the target gene sequence and two loop primers react with the target gene to form a loop structure and then robustly amplify the target gene at $58-65{ }^{\circ} \mathrm{C}$ using Bst or Bsm polymerases with DNA-strand displacement activity $[18,19]$.

To shorten the time for diagnosis, fast nucleic acid extraction from Candida in blood is needed. The sensitivity of any molecular diagnostic method for the detection of fungal pathogens depends on the lysis efficiency of fungal cells from blood samples and purification of DNA without PCR inhibitors [20]. In particular, the breakdown of the fungal cell wall is a crucial step for lysis of the cell entity and isolation of genomic DNA. Current fungal DNA extraction protocols involve enzymatic [21,22], chemical or physical disruption steps [23,24], bead beating using glass [25], or ceramic beads [26] to disrupt the fungal cell wall. Unlike nucleic acid extraction of animal cells or viruses, the additional cell wall disruption step makes rapid nucleic acid extraction from fungi more difficult.

In this study, we developed a Chelex-100/boiling DNA extraction method (within $20 \mathrm{~min}$ ) and Candida Pan/IC LAMP assay (40 $\mathrm{min}$ ) for the rapid diagnosis of candidemia. The performance of the Chelex-100 DNA extraction method was compared and evaluated with that of the QIAamp UCP Pathogen Mini Kit using general Candida qPCR. In addition, the sensitivity and specificity of the Candida Pan/IC LAMP assay were compared with those of two general qPCRs (Candida Pan and Candida species) for two kinds of clinical sample DNAs, which were extracted using the QIAamp UCP Pathogen Mini Kit and Chelex-100/boiling DNA extraction.

\section{Materials and Methods}

\subsection{Clinical Samples}

A total of 136 clinical whole blood samples were collected from Candida-infected ( $n=36)$ and non-infected patients (normal control, $\mathrm{n}=100$ ) at Korea University Guro Hospital from January 2019 to August 2021. All clinical samples were confirmed by VITEK 2 COMPACT system (bioMérieux, Durham, NC, USA) using a VITEK ${ }^{\circledR} 2$ YST ID card (bioMérieux, Durham, NC, USA). True positives included clinical blood samples infected with $C$. albicans $(n=9), C$. glabrata $(n=9)$, C. tropicalis $(n=9)$ and C. parapsilosis $(n=9)$. For the cross-reactivity test, the cultured bacteria samples, including Escherichia coli, Enterococcus faecium, Klebsiella spp., Staphylococcus aureus and Staphylococcus epidermidis, were obtained from the Korea University Guro Hospital. The study was conducted in accordance with the guidelines of the Declaration of Helsinki and was approved by the Institutional Review Board of Korea University Guro Hospital (2020GR0512).

\subsection{Isolation of Genomic DNA from Candida Strains}

Candida albicans (CCARM 14029), C. krusei (CCARM 14017), C. tropicalis (CCARM14019), C. parapsilosis (CCARM14016), C. auris (KCTC17850) and C. glabrata (KCTC 7219) were obtained from the Culture Collection of Antimicrobial-Resistant Microbes (CCARM; Seoul, Korea) and Korean Collection for Type Cultures (KCTC; Daejeon, Korea). For DNA extraction from Candida cell stocks, the yeasts were grown on yeast peptone dextrose (YPD) broth (Difco $\mathrm{BD}$, Milan, Italy) at $180 \mathrm{rpm}$ and $37^{\circ} \mathrm{C}$ overnight. After cell counting with phase-contrast 
microscopy $(40 \times$ power $)$ using a counting grid, DNA was extracted from the Candida cells $\left(\sim 2 \times 10^{8}\right.$ cells $\left./ \mathrm{mL}\right)$ using the QIAamp UCP Pathogen Mini Kit according to the manufacturer's manual.

\subsection{Isolation of Candida Genomic DNA from Whole Blood}

DNA extraction was performed using two different methods, the QIAamp UCP Pathogen Mini Kit (Qiagen, Hilden, Germany) and a newly developed simple boiling method using Chelex-100. First, DNA was extracted from the blood samples using the QIAamp UCP Pathogen Mini Kit and Lysing Matrix C tube (MP Biomedicals, Illkirch, France) according to the manufacturer's instructions, and Candida DNA was eluted with $100 \mu \mathrm{L}$ of elution buffer. Second, Candida DNA was extracted from the blood samples using the boiling method with Chelex-100 (Figure 1). Briefly, $200 \mu \mathrm{L}$ of $2 \times$ red blood cell lysis buffer (Bio Basic, Toronto, ON, Canada) was added to $200 \mu \mathrm{L}$ of whole blood sample. The sample was vortexed for $15 \mathrm{~s}$ first, followed by incubation at room temperature for $3 \mathrm{~min}$ and, later, centrifuged at 10,000 rpm for $5 \mathrm{~min}$. After removing the supernatant, $500 \mu \mathrm{L}$ of $10 \%$ Chelex-100 Resin (Bio-Rad Laboratories, Hercules, CA, USA) solution (10 mM Tris- $\mathrm{HCl}$ and $1 \mathrm{mM}$ EDTA; $\mathrm{pH}$ 8.0) was added to the pellets. The suspension was boiled for $10 \mathrm{~min}$ at $100{ }^{\circ} \mathrm{C}$ in a heat block and then vortexed for $15 \mathrm{~s}$ three times. After filtration with a $3 \mu \mathrm{m}$ Polycarbonate track-etched membrane filter (Whatman, Marlborough, UK), the supernatant was transferred to a new tube for subsequent experiments. The filtration process was performed using a SEPARA ${ }^{\circledR}$ tube (GVS, Bologna, Italy). A $3 \mu \mathrm{m}$ membrane was attached to the filtering unit using instant adhesive (UNITECH, Gyeonggi, Korea) after removing the existing filter $(0.2 \mu \mathrm{m})$.

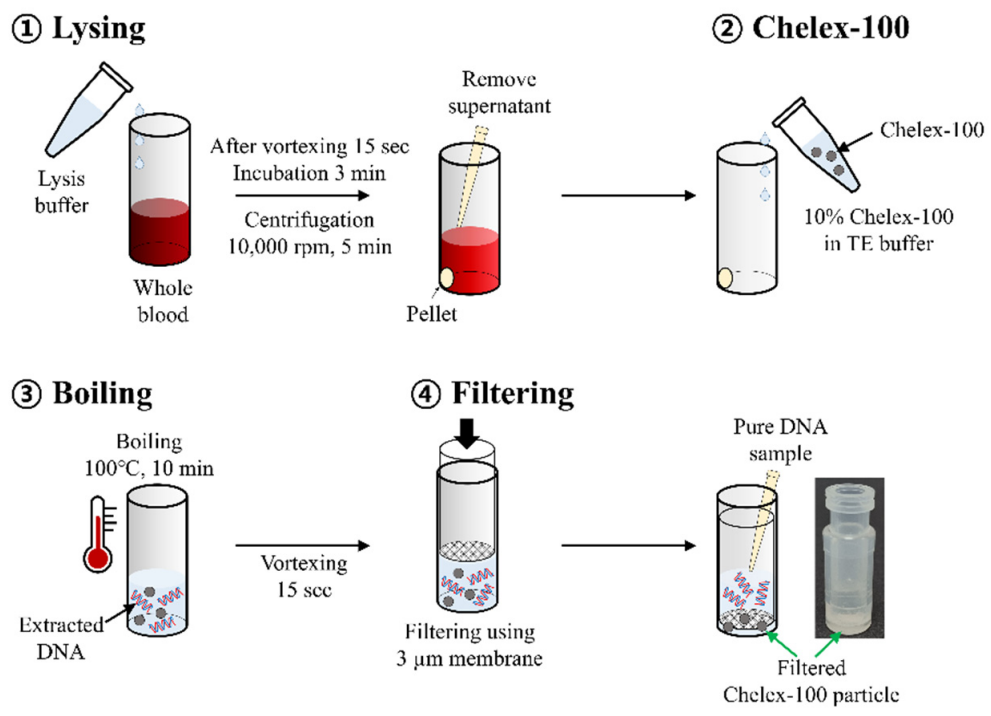

Figure 1. Schematic of Chelex-100/boiling DNA extraction method.

\subsection{Primer Design}

The Candida Pan LAMP primer set was designed within the conserved regions of partial ITS1, 5.8S rRNA gene and partial ITS2 of 6 Candida species (C. albicans MT640022.1_70-499, C. glabrata MT548912.1_350-885, C. krusei MZ507554.1_50-538, C. tropicalis LC639851.1_50601, C. parapsilosis LC641867.1_130-786 and C. auris OL455790.1_1-300). For internal control, the LAMP primer set was designed within the conserved human glucose 6 phosphatase dehydrogenase (G6PD) gene. All LAMP primers, including two outer primers (forward primer F3 and backward primer B3), two inner primers (forward inner primer FIP and backward inner primer BIP) and two loop primers (forward loop primer FLP and backward loop primer BLP), were designed using Primer Explorer software (Version 4; Eiken Chemical Co., Tokyo, Japan). For the multiplex LAMP assay, a dye-labeled artificial nucleic acid + BLP sequence probe and a quencher-labeled displacement probe complementary to the artificial 
nucleic acid sequence were used. In this study, two types of artificial nucleic acids (35 mers and 32 mers) were used for multiplexing different fluorescence (Cy5 and Texas Red) quenched by BHQ2 and BHQ1, respectively. A Cy5-labeled 35-artificial oligomer-Ca Pan BLP was designed for Ca Pan BLP probe 1 and a Texas Red-labeled 32-artificial oligomer-internal control BLP was designed for internal control BLP probe 2. The quencher-labeled 35-oligonucleotide (BHQ2) or 30-oligonucleotide (BHQ1) were complementary to the artificial nucleic acid sequences of Ca Pan BLP probe 1 and internal control BLP probe 2, respectively. All primers were assessed for specificity before use in the LAMP assays via a BLAST search of sequences in GenBank (National Center for Biotechnology Information (NCBI), Bethesda, MD). All LAMP primers and probes were synthesized by Macrogen Inc. (Seoul, Korea; Table 1).

\subsection{The Candida Pan/IC LAMP Assay}

The Candida Pan/IC LAMP assay was performed using a Mmiso DNA amplification kit (Mmonitor, Deagu, South Korea). For the multiplex Candida Pan/IC LAMP assay, the reaction mixture was prepared with $12.5 \mu \mathrm{L}$ of $2 \times$ reaction buffer, $1.25 \mu \mathrm{L}$ of Candida Pan LAMP primer mix $(20 \times), 0.3125 \mu \mathrm{L}$ of internal control LAMP primer mix $(20 \times), 1.25 \mu \mathrm{L}$ of $9 \mu \mathrm{M}$ quencher 1 solution for quenching the Candida Pan LAMP probe, $0.3125 \mu \mathrm{L}$ of $9 \mu \mathrm{M}$ quencher 2 solution for quenching the IC LAMP probe and $2 \mu \mathrm{L}$ of sample DNA (with a final reaction volume of $25 \mu \mathrm{L}$ ). The composition of the Candida Pan LAMP primer mix $(20 \times)$ included two outer primers at $4 \mu \mathrm{M}$ (F3 and B3), two inner primers at $32 \mu \mathrm{M}$ (FIP and $\mathrm{BIP}$ ), $10 \mu \mathrm{M}$ loopF primer (FLP), $4 \mu \mathrm{M}$ loopB primer (BLP) and $6 \mu \mathrm{M}$ loopB Cy5 probe. The composition of the internal control LAMP primer mix included two outer primers at $4 \mu \mathrm{M}$ (F3 and B3), two inner primers at $32 \mu \mathrm{M}$ (FIP and BIP), $10 \mu \mathrm{M}$ loopF primer (FLP), $4 \mu \mathrm{M}$ loopB primer (BLP) and $6 \mu \mathrm{M}$ loopB Texas Red probe. The LAMP assay was run on a CFX 96 Touch Real-Time PCR Detection System (Bio-Rad Laboratories, Hercules, CA, USA) at $58^{\circ} \mathrm{C}$ for $40 \mathrm{~min}$. In the LAMP assay, negative controls (human blood DNA and distilled water) were used to set the baseline.

\subsection{Real-Time PCR}

To evaluate the performance of the Candida Pan/IC LAMP assay, real-time PCR was performed with Candida Pan [27] and Candida species real-time PCR primer sets [28,29] using the iQ Multiplex Powermix (Bio-Rad Laboratories, California, USA) on the CFX96 Touch Real-Time PCR Detection System (Bio-Rad Laboratories). The PCR cycling conditions of Candida Pan real-time PCR primer set were as follows: inactivation at $95^{\circ} \mathrm{C}$ for $3 \mathrm{~min}$, 39 cycles of denaturation at $95^{\circ} \mathrm{C}$ for $15 \mathrm{~s}$ and annealing with fluorescence detection at $62{ }^{\circ} \mathrm{C}$ for $25 \mathrm{~s}$. The PCR cycling conditions of the Candida species real-time PCR primer set were as follows: inactivation at $50{ }^{\circ} \mathrm{C}$ for $2 \mathrm{~min}$ and $95^{\circ} \mathrm{C}$ for $10 \mathrm{~min}, 39$ cycles of denaturation at $95^{\circ} \mathrm{C}$ for $15 \mathrm{~s}$ and annealing with fluorescence detection at $60^{\circ} \mathrm{C}$ for $1 \mathrm{~min}$.

\subsection{Limit of Detection (LOD) Tests}

The LOD of the Candida Pan/IC LAMP was determined using six Candida spp., including C. albicans, C. krusei, C. tropicalis, C. parapsilosis, C. auris and C. glabrata. Candida DNA $\left(1.0 \times 10^{7}\right.$ cells $)$ was serially diluted 10 -fold, from $1.0 \times 10^{7}$ cells $/ \mu \mathrm{L}$ to $1.0 \times 10^{0}$ cells $/ \mu \mathrm{L}$ and used to determine the LOD of the multiplex Candia Pan/IC LAMP assay. In addition, the LOD of the Candida Pan/IC LAMP was tested with serially diluted blood samples spiked with $C$. albicans (from $10^{7}$ to $10^{0}$ ). The LOD of the Candida Pan/IC LAMP assay was compared with that of the conventional Candida Pan RT-PCR. All tests were repeated three times and determined as the minimum concentration in a 10-fold dilution series, at which three of three replicates were amplified.

\subsection{Statistical Analysis}

The confidence intervals (CI) for sensitivity and specificity were set at $95 \%$. The sensitivity, specificity and 95\% CI for the assays were calculated using a diagnostic test evaluation 
calculator program (https://www.medcalc.org/calc/diagnostic_test.php, accessed on 21 December 2021).

Table 1. The LAMP primer sets and qPCR primer sets used in the study.

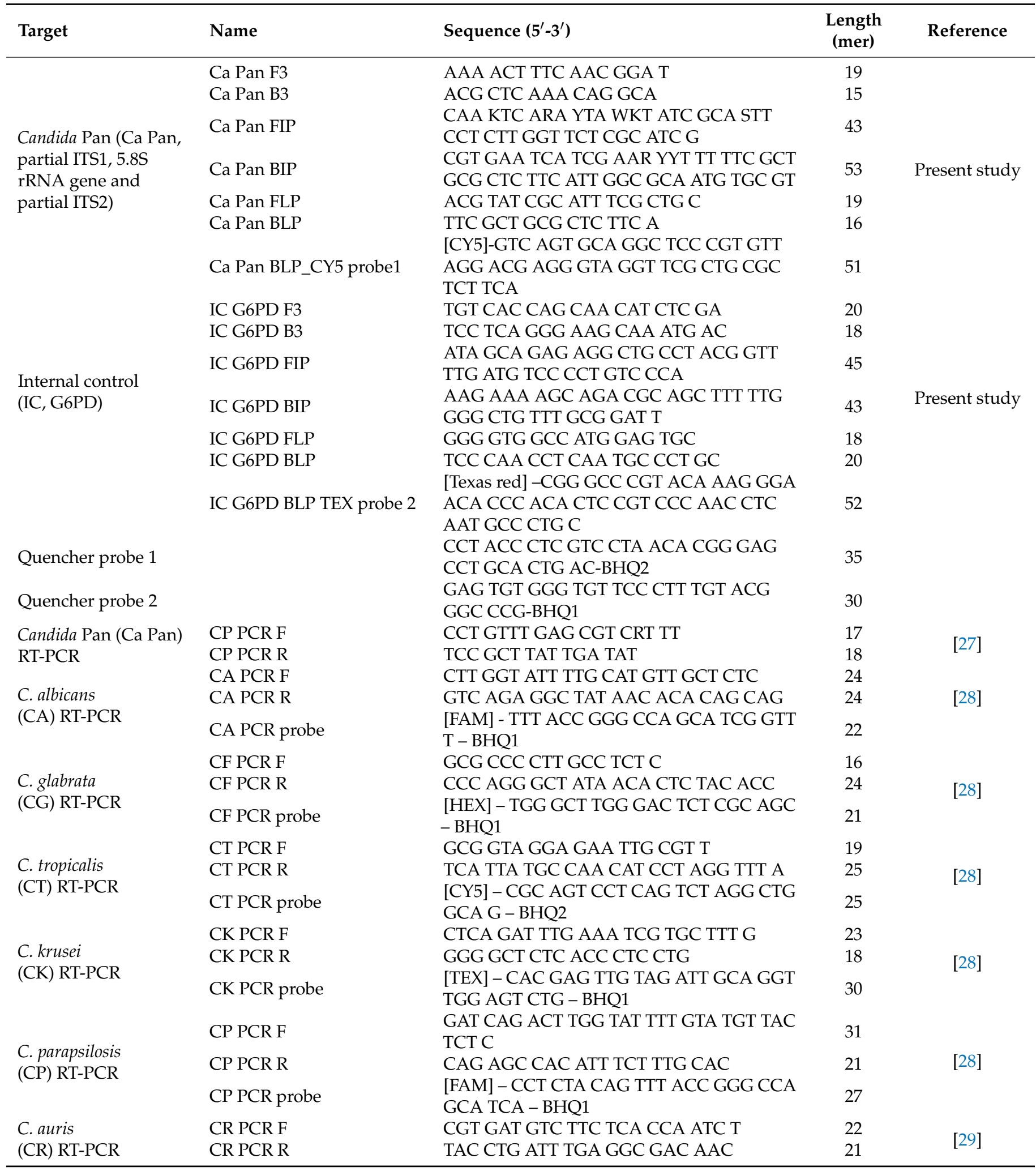




\section{Results}

\subsection{Optimization of the Chelex-100/Boiling Method for Nucleic Acid Extraction}

To optimize the Chelex-100/boiling method, different concentrations of the Chelex 100 Resin solutions ( $0 \%, 5 \%$ and $10 \%)$ were tested using C. albicans real-time PCR and the Candida Pan/IC LAMP assay for C. albicans DNA extracted from the whole blood samples spiked with Candida cells (total cell concentration of $10^{7} / \mathrm{mL}$ ) (Figure 2A). For DNA extraction with $0 \%, 5 \%$ and $10 \%$ Chelex-100 resin solutions, real-time PCR and the Candida Pan/IC LAMP assay showed Ct 28.84/26.16/25.05 and Ct 13.59/13.49/12.75, respectively. Thus, the $10 \%$ Chelex-100 resin solution was determined to be the optimum concentration of Chelex-100 for the Chelex-100/boiling method. Next, the performance of the Chelex-100/boiling method was compared with that of the commercial QIAamp UCP Pathogen Mini Kit (Qiagen, Hilden, Germany) against whole blood samples spiked with C. albicans using C. albicans qPCR and Candida Pan/IC LAMP assay (Figure 2B, Table 2). As a result, the detection limits of the C. albicans qPCR primer set were $10^{5} / \mathrm{mL}$ and $10^{4} / \mathrm{mL}$ in DNA samples extracted using the Chelex-100/boiling and QIAamp UCP Pathogen Mini Kit, respectively. Interestingly, the Candida Pan/IC LAMP assay showed lower detection limits $\left(10^{4} / \mathrm{mL}\right.$ and $\left.10^{3} / \mathrm{mL}\right)$ than those obtained by qPCR for DNA extracted using the Chelex-100/boiling and QIAamp UCP Pathogen Mini Kit, respectively. Although the Chelex-100/boiling method showed lower efficiency than the commercial QIAamp UCP Pathogen Mini Kit, Candida Pan/IC LAMP, followed by Chelex-100/boiling DNA extraction, showed similar results to qPCR for DNA samples extracted using the QIAamp UCP Pathogen Mini Kit. These results suggest that the Candida Pan/IC LAMP with Chelex100/boiling DNA extraction is useful for the rapid diagnosis of candidemia.

A
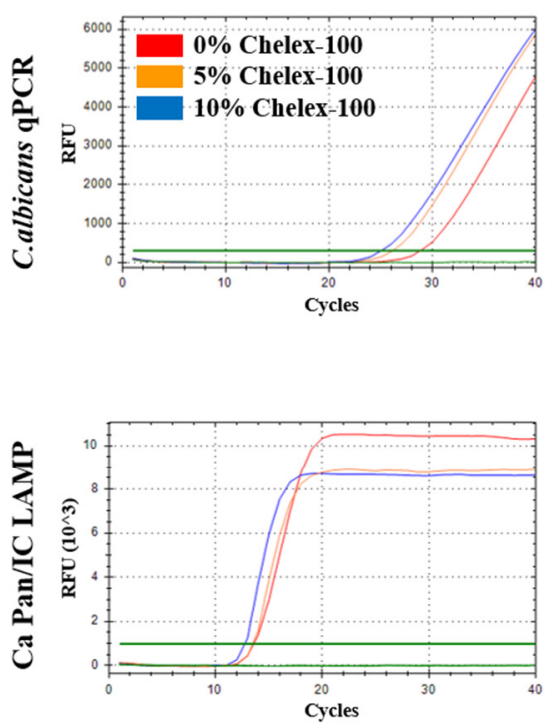

\section{B}
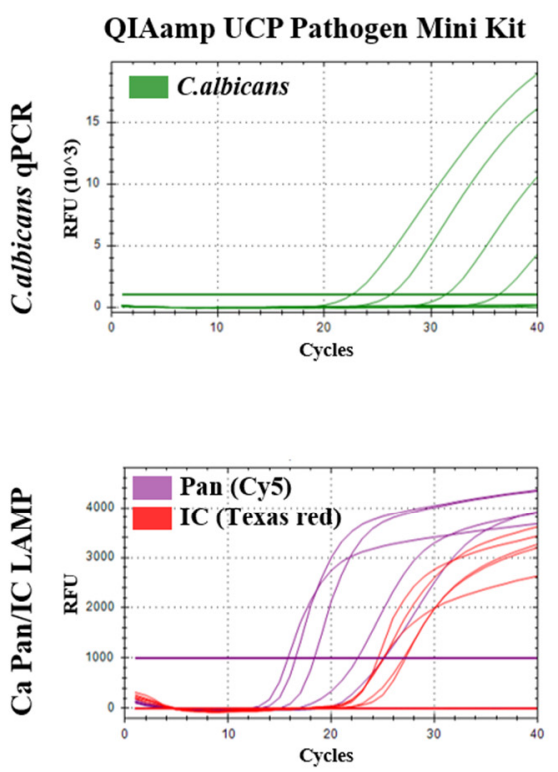

Chelex-100/boiling method
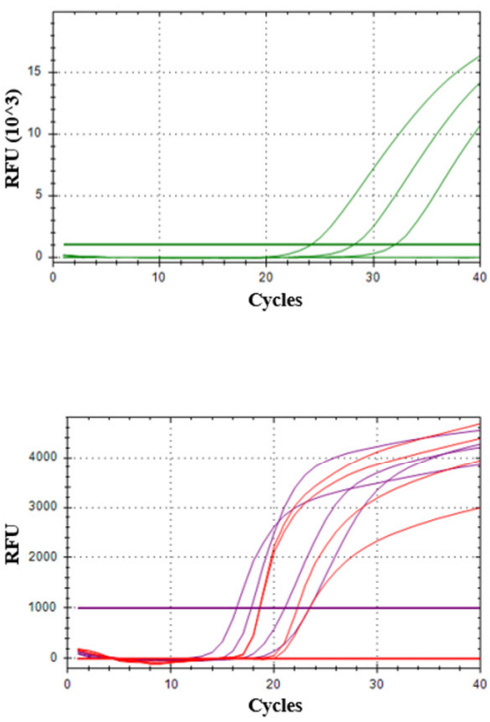

Figure 2. Optimization of the Chelex-100/boiling DNA extraction method. (A) Different concentration ratios of Chelex-100 (0\%, 5\% and 10\%). (B) Comparison of detection limit of Candida albicans qPCR and Candida Pan/IC LAMP assay on two kinds of 10-fold serial diluted DNA samples extracted by Chelex-100/boiling and QIAamp UCP Pathogen Mini Kit, respectively. 
Table 2. Limit of detection (LOD) tests of Candida species qPCRs and the Candida Pan/IC LAMP assay for two Candida-spiked blood DNA samples extracted by QIAamp UCP Pathogen Mini Kit and Chelex-100/boiling method.

\begin{tabular}{|c|c|c|c|c|c|c|c|c|c|c|}
\hline \multirow{2}{*}{$\begin{array}{c}\text { DNA Extraction } \\
\text { Method }\end{array}$} & \multirow{2}{*}{$\begin{array}{c}\text { PCR } \\
\text { Analysis }\end{array}$} & \multirow{2}{*}{ Primer Sets } & \multicolumn{8}{|c|}{ Total Concentration (cells/mL) } \\
\hline & & & $10^{7}$ & $10^{6}$ & $10^{5}$ & $10^{4}$ & $10^{3}$ & $10^{2}$ & $10^{1}$ & DW * \\
\hline \multirow{3}{*}{$\begin{array}{c}\text { QIAamp UCP } \\
\text { Pathogen Mini Kit }\end{array}$} & qPCR & C. albicans & 22.48 & 26.15 & 31.29 & 36.27 & $\mathrm{~N} / \mathrm{A}$ & $\mathrm{N} / \mathrm{A}$ & $\mathrm{N} / \mathrm{A}$ & $\mathrm{N} / \mathrm{A}$ \\
\hline & Multiplex & Cy5 (c. pan) & 15.80 & 16.53 & 18.35 & 22.54 & 25.14 & $\mathrm{~N} / \mathrm{A}$ & $\mathrm{N} / \mathrm{A}$ & $\mathrm{N} / \mathrm{A}$ \\
\hline & RT LAMP & Tex (IC) & 25.01 & 27.20 & 27.01 & 24.53 & 25.10 & $\mathrm{~N} / \mathrm{A}$ & $\mathrm{N} / \mathrm{A}$ & $\mathrm{N} / \mathrm{A}$ \\
\hline \multirow{3}{*}{$\begin{array}{c}\text { Chelex- } \\
\text { 100/boiling }\end{array}$} & qPCR & C. albicans & 24.12 & 28.11 & 31.99 & $\mathrm{~N} / \mathrm{A}$ & $\mathrm{N} / \mathrm{A}$ & $\mathrm{N} / \mathrm{A}$ & $\mathrm{N} / \mathrm{A}$ & $\mathrm{N} / \mathrm{A}$ \\
\hline & Multiplex & Cy5 (c. pan) & 16.36 & 17.78 & 21.04 & 23.43 & $\mathrm{~N} / \mathrm{A}$ & $\mathrm{N} / \mathrm{A}$ & $\mathrm{N} / \mathrm{A}$ & $\mathrm{N} / \mathrm{A}$ \\
\hline & RT LAMP & $\operatorname{Tex}(\mathrm{IC})$ & 23.43 & 22.25 & 18.63 & 18.59 & $\mathrm{~N} / \mathrm{A}$ & N/A & $\mathrm{N} / \mathrm{A}$ & $\mathrm{N} / \mathrm{A}$ \\
\hline
\end{tabular}

${ }^{*}$ DW, distilled water; N/A, not available.

3.2. Comparison of Detection Limits of the Candida Pan/IC LAMP Assay and Two qPCR (Pan and Candida Species) against Candida Species

To confirm the performance of the Candida Pan/IC LAMP assay, the detection limit of the LAMP assay was compared with that of Candida Pan/Candida species qPCRs for six Candida species, including C. albicans, C. glabrata, C. tropicalis, C. krusei, C. parapsilosis and C. auris. DNA samples from all Candida species were extracted using the QIAamp UCP Pathogen Mini Kit (Table 3). For C. albicans and C. krusei, the Candida Pan/IC LAMP assay showed the lowest detection limit $\left(10^{3}\right)$ among the three tested assays. The detection limits of Candida Pan qPCR and Candida species qPCR (C. albicans and C. krusei) [28] were 105/10 and $10^{4} / 10^{5}$ for C. albicans and C. krusei, respectively. For C. glabrata and C. tropicalis, the Candida Pan/IC LAMP assay and Candida species qPCR (C. glabrata and C. tropicalis) [28] showed the same detection limit $\left(10^{5}\right)$. The detection limit of Candida Pan qPCR was $10^{6} / 10^{6}$ for C. glabrata and C. tropicalis, respectively. qPCR specific for C. parapsilosis [28] and $C$. auris [29] showed the lowest detection limit $\left(10^{4}\right)$ among the three tested assays. The detection limits of Candida Pan qPCR were $10^{6}$ and $10^{7}$ for C. parapsilosis and C. auris, respectively. The Candida Pan/IC LAMP assay showed the same detection limits $\left(10^{5}\right)$ for C. parapsilosis and C. auris.

\subsection{Sensitivity and Specificity of the Candida Pan/IC LAMP Assay with Two qPCR Assays against Candida Clinical Sample DNA Extracted by QIAamp UCP Pathogen Mini Kit and Chelex-100/Boiling Method}

To confirm the clinical performance of the Chelex-100/boiling DNA extraction method and the Candida Pan/IC LAMP assay, DNA extraction was performed using two different methods, the QIAamp UCP Pathogen Mini Kit and Chelex-100/boiling method; the sensitivities of the Candida Pan/IC LAMP assay were compared with those of the Candida Pan qPCR and specific Candida species qPCR for 36 clinical samples from patients infected with C. albicans (9), C. glabrata (9), C. tropicalis (9) and C. parapsilosis (9) (Table 4). Within $40 \mathrm{~min}$, the Candida Pan/IC LAMP assay showed 100\% sensitivity for two kinds of Candida clinical sample DNA extracted by QIAamp UCP Pathogen Mini Kit and Chelex-100/boiling method, respectively. Conventional Candida Pan and Candida species qPCR showed the same sensitivity $(86.11 \%)$ for 36 Candida clinical sample DNA extracted using the QIAamp UCP Pathogen Mini Kit. However, for Candida clinical sample DNA extracted by the Chelex-100/boiling method, the Candida Pan qPCR and Candida species qPCR showed $22 \%$ and $44 \%$ sensitivity, respectively. For 100 negative clinical samples (non-infected), the specificity of the three assays was $100 \%$ (Table 4).

\subsection{Cross-Reactivity Test}

To confirm the possibility of cross-reactivity of the Candida Pan/IC LAMP assay, the Candida Pan/IC LAMP assay was tested with other bacterial samples, including Escherichia coli, Enterococcus faecium, Klebsiella spp., Staphylococcus aureus and Staphylococcus epidermidis samples (Table 5). The Candida Pan/IC LAMP assay showed no cross-reactivity 
with other fungal infection samples, suggesting that the LAMP assay can specifically detect Candida species.

Table 3. Limit of detection (LOD) tests of Pan/Candida species qPCRs and the Candida Pan/IC LAMP assay for 6 Candida spp.

\begin{tabular}{|c|c|c|c|c|c|c|c|c|c|c|}
\hline \multirow{2}{*}{$\begin{array}{l}\text { Candida } \\
\text { Species }\end{array}$} & \multirow{2}{*}{\multicolumn{2}{|c|}{ Primer Sets }} & \multicolumn{8}{|c|}{ Total Concentration (Cells $/ \mathrm{mL})$} \\
\hline & & & $10^{7}$ & $10^{6}$ & $10^{5}$ & $10^{4}$ & $10^{3}$ & $10^{2}$ & $10^{1}$ & DW * \\
\hline \multirow{4}{*}{ C. albicans } & \multirow{2}{*}{ qPCR } & Candida Pan & 24.17 & 32.71 & 36.66 & $\mathrm{~N} / \mathrm{A}$ & $\mathrm{N} / \mathrm{A}$ & N/A & $\mathrm{N} / \mathrm{A}$ & $\mathrm{N} / \mathrm{A}$ \\
\hline & & C. albicans & 22.50 & 26.60 & 31.35 & 39.78 & $\mathrm{~N} / \mathrm{A}$ & N/A & $\mathrm{N} / \mathrm{A}$ & $\mathrm{N} / \mathrm{A}$ \\
\hline & \multirow{2}{*}{ LAMP } & Cy5 (c. pan) & 15.20 & 16.75 & 22.45 & 27.44 & 28.01 & N/A & $\mathrm{N} / \mathrm{A}$ & $\mathrm{N} / \mathrm{A}$ \\
\hline & & Tex (IC) & N/A & N/A & N/A & N/A & N/A & N/A & $\mathrm{N} / \mathrm{A}$ & $\mathrm{N} / \mathrm{A}$ \\
\hline \multirow{4}{*}{ C. glabrata } & \multirow{2}{*}{ qPCR } & Candida Pan & 22.02 & 31.08 & N/A & $\mathrm{N} / \mathrm{A}$ & $\mathrm{N} / \mathrm{A}$ & N/A & $\mathrm{N} / \mathrm{A}$ & $\mathrm{N} / \mathrm{A}$ \\
\hline & & C. glabrata & 21.07 & 28.25 & 35.50 & $\mathrm{~N} / \mathrm{A}$ & $\mathrm{N} / \mathrm{A}$ & $\mathrm{N} / \mathrm{A}$ & $\mathrm{N} / \mathrm{A}$ & $\mathrm{N} / \mathrm{A}$ \\
\hline & \multirow{2}{*}{ LAMP } & Cy5 (c. pan) & 15.04 & 17.4 . & 23.76 & $\mathrm{~N} / \mathrm{A}$ & $\mathrm{N} / \mathrm{A}$ & N/A & $\mathrm{N} / \mathrm{A}$ & $\mathrm{N} / \mathrm{A}$ \\
\hline & & Tex (IC) & N/A & N/A & N/A & N/A & N/A & N/A & $\mathrm{N} / \mathrm{A}$ & $\mathrm{N} / \mathrm{A}$ \\
\hline \multirow{4}{*}{ C. tropicalis } & \multirow{2}{*}{ qPCR } & Candida Pan & 22.27 & 30.38 & N/A & N/A & N/A & N/A & $\mathrm{N} / \mathrm{A}$ & $\mathrm{N} / \mathrm{A}$ \\
\hline & & C. tropicalis & 23.69 & 29.22 & 36.38 & $\mathrm{~N} / \mathrm{A}$ & $\mathrm{N} / \mathrm{A}$ & N/A & $\mathrm{N} / \mathrm{A}$ & $\mathrm{N} / \mathrm{A}$ \\
\hline & \multirow{2}{*}{ LAMP } & Cy5 (c. pan) & 15.76 & 18.36 & 26.04 & N/A & N/A & N/A & $\mathrm{N} / \mathrm{A}$ & $\mathrm{N} / \mathrm{A}$ \\
\hline & & Tex (IC) & N/A & N/A & $\mathrm{N} / \mathrm{A}$ & $\mathrm{N} / \mathrm{A}$ & $\mathrm{N} / \mathrm{A}$ & N/A & $\mathrm{N} / \mathrm{A}$ & $\mathrm{N} / \mathrm{A}$ \\
\hline \multirow{4}{*}{ C. krusei } & \multirow{2}{*}{ qPCR } & Candida Pan & 20.60 & 28.44 & N/A & N/A & N/A & $\mathrm{N} / \mathrm{A}$ & $\mathrm{N} / \mathrm{A}$ & $\mathrm{N} / \mathrm{A}$ \\
\hline & & C. krusei & 22.46 & 28.42 & 38.84 & N/A & N/A & N/A & $\mathrm{N} / \mathrm{A}$ & $\mathrm{N} / \mathrm{A}$ \\
\hline & \multirow[b]{2}{*}{ LAMP } & Cy5 (c. pan) & 17.00 & 19.31 & 25.34 & 34.45 & N/A & N/A & $\mathrm{N} / \mathrm{A}$ & $\mathrm{N} / \mathrm{A}$ \\
\hline & & Tex (IC) & N/A & $\mathrm{N} / \mathrm{A}$ & $\mathrm{N} / \mathrm{A}$ & $\mathrm{N} / \mathrm{A}$ & $\mathrm{N} / \mathrm{A}$ & N/A & $\mathrm{N} / \mathrm{A}$ & $\mathrm{N} / \mathrm{A}$ \\
\hline \multirow{4}{*}{ C. parapsilosis } & \multirow{2}{*}{ qPCR } & Candida Pan & 20.38 & 24.85 & 34.73 & N/A & N/A & N/A & N/A & N/A \\
\hline & & C. parapsilosis & 21.34 & 25.80 & 31.48 & 36.97 & N/A & N/A & $\mathrm{N} / \mathrm{A}$ & $\mathrm{N} / \mathrm{A}$ \\
\hline & \multirow[b]{2}{*}{ LAMP } & Cy5 (c. pan) & 17.80 & 20.34 & 28.92 & N/A & N/A & N/A & $\mathrm{N} / \mathrm{A}$ & $\mathrm{N} / \mathrm{A}$ \\
\hline & & Tex (IC) & N/A & N/A & N/A & N/A & N/A & N/A & $\mathrm{N} / \mathrm{A}$ & $\mathrm{N} / \mathrm{A}$ \\
\hline \multirow{4}{*}{ C. auris } & \multirow{2}{*}{ qPCR } & Candida Pan & 35.51 & N/A & N/A & $\mathrm{N} / \mathrm{A}$ & $\mathrm{N} / \mathrm{A}$ & N/A & $\mathrm{N} / \mathrm{A}$ & $\mathrm{N} / \mathrm{A}$ \\
\hline & & C. auris & 21.59 & 25.14 & 30.21 & 36.63 & $\mathrm{~N} / \mathrm{A}$ & N/A & $\mathrm{N} / \mathrm{A}$ & $\mathrm{N} / \mathrm{A}$ \\
\hline & \multirow{2}{*}{ LAMP } & Cy5 (c. pan) & 15.97 & 17.54 & 21.58 & $\mathrm{~N} / \mathrm{A}$ & N/A & N/A & $\mathrm{N} / \mathrm{A}$ & $\mathrm{N} / \mathrm{A}$ \\
\hline & & Tex (IC) & N/A & N/A & N/A & $\mathrm{N} / \mathrm{A}$ & $\mathrm{N} / \mathrm{A}$ & N/A & $\mathrm{N} / \mathrm{A}$ & $\mathrm{N} / \mathrm{A}$ \\
\hline
\end{tabular}

${ }^{*} \mathrm{DW}$, distilled water; N/A, not available.

Table 4. Comparison of sensitivity and specificity of multiplex Candida Pan/IC LAMP assay with reference pan and mono Candida species RT-PCR against Candida and non-infectious clinical samples.

\begin{tabular}{|c|c|c|c|c|c|c|c|c|c|}
\hline \multirow{3}{*}{\multicolumn{2}{|c|}{ Clinical Samples }} & \multicolumn{4}{|c|}{ QIAamp UCP Pathogen Mini Kit } & \multicolumn{4}{|c|}{ Boiling and Filtering Method } \\
\hline & & \multicolumn{2}{|c|}{ qPCR } & \multicolumn{2}{|c|}{$\begin{array}{l}\text { Multiplex } \\
\text { LAMP }\end{array}$} & \multicolumn{2}{|c|}{ qPCR } & \multicolumn{2}{|c|}{$\begin{array}{l}\text { Multiplex } \\
\text { LAMP }\end{array}$} \\
\hline & & $\begin{array}{c}\text { Candida } \\
\text { pan }\end{array}$ & $\begin{array}{l}\text { Candida } \\
\text { Species }\end{array}$ & $\begin{array}{c}\text { Cy5 } \\
\text { (C. pan) }\end{array}$ & $\begin{array}{l}\text { Tex } \\
\text { (IC) }\end{array}$ & $\begin{array}{c}\text { Candida } \\
\text { pan }\end{array}$ & $\begin{array}{l}\text { Candida } \\
\text { Species }\end{array}$ & $\begin{array}{c}\text { Cy5 } \\
\text { (C. pan) }\end{array}$ & $\begin{array}{l}\text { Tex } \\
\text { (IC) }\end{array}$ \\
\hline \multirow[b]{2}{*}{$\begin{array}{l}\text { Candida Spp. } \\
\quad(\mathrm{n}=36)\end{array}$} & $\mathrm{P} / \mathrm{N}$ & $31 / 5$ & $31 / 5$ & $36 / 0$ & $27 / 9$ & $8 / 28$ & $16 / 20$ & $36 / 0$ & $28 / 8$ \\
\hline & $\begin{array}{l}\text { Sensitivity } \\
\text { (95\% CI- }\end{array}$ & $\begin{array}{c}86.11 \% \\
{[70.50-95.33]}\end{array}$ & $\begin{array}{c}86.11 \% \\
{[70.50-95.33]}\end{array}$ & $\begin{array}{c}100 \% \\
{[90.26-} \\
100.00]\end{array}$ & $\begin{array}{c}75.00 \% \\
{[57.80-87.88]}\end{array}$ & $\begin{array}{c}22.22 \% \\
{[10.12-39.15]}\end{array}$ & $\begin{array}{c}44.44 \% \\
{[27.94-61.90]}\end{array}$ & $\begin{array}{c}100 \% \\
{[90.26-} \\
100.00]\end{array}$ & $\begin{array}{c}77.77 \% \\
{[60.85-89.88]}\end{array}$ \\
\hline \multirow{2}{*}{$\begin{array}{l}\text { C. albicans } \\
(\mathrm{n}=9)\end{array}$} & $\mathrm{P} / \mathrm{N}$ & $8 / 1$ & $8 / 1$ & $9 / 0$ & $6 / 3$ & $1 / 8$ & $5 / 4$ & $9 / 0$ & $9 / 0$ \\
\hline & Sensitivity & $88.89 \%$ & $88.89 \%$ & $100 \%$ & $66.67 \%$ & $11.11 \%$ & $55.56 \%$ & $100 \%$ & $100 \%$ \\
\hline \multirow{2}{*}{$\begin{array}{l}\text { C. glabrata } \\
(\mathrm{n}=9)\end{array}$} & $\mathrm{P} / \mathrm{N}$ & $8 / 1$ & $8 / 1$ & $9 / 0$ & $7 / 2$ & $2 / 7$ & $3 / 6$ & $9 / 0$ & $6 / 3$ \\
\hline & Sensitivity & $88.89 \%$ & $88.89 \%$ & $100 \%$ & $77.78 \%$ & $22.22 \%$ & $33.33 \%$ & $100 \%$ & $66.67 \%$ \\
\hline \multirow{2}{*}{$\begin{array}{l}\text { C. tropicalis } \\
(\mathrm{n}=9)\end{array}$} & $\mathrm{P} / \mathrm{N}$ & $6 / 3$ & $6 / 3$ & $9 / 0$ & $8 / 1$ & $2 / 7$ & $3 / 6$ & $9 / 0$ & $6 / 3$ \\
\hline & Sensitivity & $66.67 \%$ & $66.67 \%$ & $100 \%$ & $88.89 \%$ & $22.22 \%$ & $33.33 \%$ & $100 \%$ & $66.67 \%$ \\
\hline \multirow{3}{*}{$\begin{array}{l}\text { C. parapsilosis } \\
\qquad(\mathrm{n}=9)\end{array}$} & $\mathrm{P} / \mathrm{N}$ & $9 / 0$ & $9 / 0$ & $9 / 0$ & $6 / 3$ & $3 / 6$ & $5 / 4$ & $9 / 0$ & $7 / 2$ \\
\hline & Sensitivity & $100 \%$ & $100 \%$ & $100 \%$ & $66.67 \%$ & $33.33 \%$ & $55.56 \%$ & $100 \%$ & $77.78 \%$ \\
\hline & $\mathrm{P} / \mathrm{N}$ & $0 / 100$ & $0 / 100$ & $0 / 100$ & $100 / 0$ & $0 / 100$ & $0 / 100$ & $0 / 100$ & $100 / 0$ \\
\hline \multirow{2}{*}{$\begin{array}{c}\text { Non- } \\
\text { infection } \\
(\mathrm{n}=100)\end{array}$} & $\begin{array}{l}\text { Sensitivity } \\
(95 \% \mathrm{CI})\end{array}$ & $\mathrm{N} / \mathrm{A}$ & $\mathrm{N} / \mathrm{A}$ & $\mathrm{N} / \mathrm{A}$ & $\begin{array}{c}100 \% \\
{[96.38-} \\
100.00]\end{array}$ & $\mathrm{N} / \mathrm{A}$ & $\mathrm{N} / \mathrm{A}$ & $\mathrm{N} / \mathrm{A}$ & $\begin{array}{c}100 \% \\
{[96.38-} \\
100.00]\end{array}$ \\
\hline & $\begin{array}{l}\text { Specificity } \\
(95 \% \text { CI })\end{array}$ & $\begin{array}{c}100 \% \\
{[96.38-} \\
100.00]\end{array}$ & $\begin{array}{c}100 \% \\
{[96.38-} \\
100.00]\end{array}$ & $\begin{array}{c}100 \% \\
{[96.38-} \\
100.00]\end{array}$ & $\mathrm{N} / \mathrm{A}$ & $\begin{array}{c}100 \% \\
{[96.38-} \\
100.00]\end{array}$ & $\begin{array}{c}100 \% \\
{[96.38-} \\
100.00]\end{array}$ & $\begin{array}{c}100 \% \\
{[96.38-} \\
100.00]\end{array}$ & $\mathrm{N} / \mathrm{A}$ \\
\hline
\end{tabular}


Table 5. Cross-reactivity of the Candida Pan/IC LAMP against other bacterial infection samples.

\begin{tabular}{|c|c|c|c|c|}
\hline \multirow[b]{3}{*}{ Samples } & \multicolumn{4}{|c|}{ Candida Pan/IC LAMP } \\
\hline & \multicolumn{2}{|c|}{$\begin{array}{c}\text { Cy5 } \\
\text { (Candida pan) }\end{array}$} & \multicolumn{2}{|c|}{$\begin{array}{c}\text { Texas Red } \\
\text { (Internal Control) }\end{array}$} \\
\hline & $\mathbf{C t}$ & RFU * & $\mathrm{Ct}$ & RFU * \\
\hline Escherichia coli & $\mathrm{N} / \mathrm{A}$ & 19.1 & $\mathrm{~N} / \mathrm{A}$ & 23.3 \\
\hline Enterococcus faecium & $\mathrm{N} / \mathrm{A}$ & 31.1 & $\mathrm{~N} / \mathrm{A}$ & 22.6 \\
\hline Klebsiella spp. & $\mathrm{N} / \mathrm{A}$ & 20.0 & $\mathrm{~N} / \mathrm{A}$ & 28.3 \\
\hline Staphylococcus aureus & $\mathrm{N} / \mathrm{A}$ & 44.0 & $\mathrm{~N} / \mathrm{A}$ & 39.0 \\
\hline Staphylococcus epidermidis & $\mathrm{N} / \mathrm{A}$ & 57.7 & $\mathrm{~N} / \mathrm{A}$ & 42.6 \\
\hline Human whole blood DNA & $\mathrm{N} / \mathrm{A}$ & -17.9 & 29.68 & 4186 \\
\hline Distilled water & $\mathrm{N} / \mathrm{A}$ & 1.76 & $\mathrm{~N} / \mathrm{A}$ & -0.889 \\
\hline
\end{tabular}

* RFU, relative fluorescence units.

\section{Discussion}

Invasive candidiasis (IC) is a serious cause of morbidity and mortality [26,30]. In the hospital, Candida spp. account for $8-9 \%$ of all nosocomial bloodstream infections and the risk is higher in intensive care unit (ICU) patients and cancer patients [31,32]. Candidemia has an associated mortality rate of up to $25 \%$ and a fast diagnosis followed by early adequate antifungal therapy can significantly reduce premature mortality [33,34].

In this study, we developed a Chelex-100/boiling DNA extraction method (within $20 \mathrm{~min}$ ) and Candida Pan/IC LAMP assay (40 min) for the rapid diagnosis of candidemia. The Chelex-100/boiling method showed a slightly lower efficiency than the commercial QIAamp UCP Pathogen Mini Kit; however, the Chelex-100/boiling DNA extraction method (within 20 min) extracted DNA 3-4 times faster than commercial QIAamp UCP Pathogen Mini kits (60-90 min). In addition, Chelex-100/boiling DNA extraction followed by the Candida Pan/IC LAMP assay showed similar results to the reference qPCR for DNA samples extracted using the QIAamp UCP Pathogen Mini Kit. Interestingly, the LAMP assay showed superior performance ( $100 \%$ sensitivity) compared with the conventional reference qPCRs ( $86.11 \%$ sensitivity) against 36 numbers of Candida clinical DNA samples extracted by both the Chelex-100/boiling method and commercial QIAamp UCP Pathogen Mini Kit. In addition, the Candida Pan/IC LAMP assay showed $100 \%$ specificity against 100 non-infected clinical samples.

As fungal cell walls are difficult to break with conventional extraction methods, obtaining DNA from fungi is more difficult than extracting nucleic acids from bacteria or mammalian cells [35]. For this reason, nucleic acid extraction methods to detect fungusinfected blood generally require additional procedures (e.g., mechanical, enzymatic and /or chemical methods) to disrupt the fungal cell wall [36]. Therefore, these nucleic acid extraction methods consist of a complicated procedure and it takes a long time to extract the nucleic acid [37].

Nucleic acid extraction using cheliex-100 is known as a fast and easy method for nucleic acid extraction from various samples, such as forensics, blood, parasites, virus and bacteria $[38,39]$. The first protocol for DNA extraction using Chelex-100 was developed by Walsh et al. [40]. Chelex-100 has been mainly used in forensics in conjunction with thermal denaturation to extract nucleic acids from trace cells or blood. Boiling the sample not only releases the DNA from the cells into the solution, but also promotes the binding of Chelex100 to the magnesium ion, which is a cofactor of deoxyribonuclease. DNA degradation is prevented because the binding of Chelex-100 to magnesium ions results in the inactivation of deoxyribonuclease. In this study, after removing red blood cells from the blood using a red blood cell lysis solution, cells that were not lysed were separated by centrifugation. After heating the separated cells using a Chelex-100 solution, the nucleic acids were separated using a $3 \mu \mathrm{m}$ filter. Additionally, a bead beating step was added to the Chelex-100/boiling method to further increase Candida cell destruction. However, there was no significant difference in the ct value of the LAMP assay, so this step was excluded (Figure S1). 
The Candida Pan LAMP primer set was designed using Primer Explorer software by multialigning conserved regions of partial ITS1, 5.8S rRNA gene and partial ITS2 genes of C. albicans, C. glabrata, C. tropicalis, C. krusei, C. parapsilosis and C. auris. However, it was not possible to design the BLP primer because B1 and B2 of the designed primer set were too close. The LOOP primer explosively amplified the LAMP reaction. In this study, for the development of the rapid Candida Pan LAMP primer set, an artificial sequence (TTCGCTGCGCTCTTCA) capable of reacting with the LOOP primer was added between $\mathrm{B} 1$ and $\mathrm{B} 2$ to design the BIP primer. Indeed, the Candida Pan LAMP primer set with the BLP primer of the same artificial sequence showed an increased reaction rate compared to the primer set without BLP (Figure S2). In addition, we used this BLP + Cy5-labeled 35-artificial oligomer as a Candida Pan probe; since the BLP of this artificial sequence is not involved in the Candida target gene, it only responds to the operation of BIP without a non-specific reaction.

Our study has a limitation. The Candida Pan/IC LAMP assay was performed with a relatively small sample size of positive Candida clinical samples (36), which resulted in widened confidence intervals for our estimates of diagnostic accuracy. However, considering that the Candida Pan/IC LAMP assay showed higher sensitivity than the two conventional PCR and $100 \%$ specificity to the negative samples, the Candida Pan/IC LAMP assay is sufficiently competitive for commercial development.

\section{Conclusions}

In this study, we developed a fast candidemia detection system including Chelex100/boiling DNA extraction and the Candida Pan/IC LAMP assay, which is capable of diagnosing Candida species in blood within $1 \mathrm{~h}$. In a sensitivity test with Candida clinical samples, the Candida Pan/IC LAMP assay showed superior performance to the two reference qPCRs. Thus, Chelex-100/boiling DNA extraction followed by the Candida Pan/IC LAMP assay could serve as a useful fast molecular diagnostic test for Candida spp. in blood.

Supplementary Materials: The following supporting information can be downloaded at: https: / / www.mdpi.com/article/10.3390/pathogens11020111/s1, Figure S1: Comparison of ct values of Candida Pan LAMP assay with/without BLP, Figure S2: Comparison of ct values of LAMP assay according to bead beat cycles (0, 5 and 10 cycles) in Chelex-100/boiling DNA extraction.

Author Contributions: Conceptualization, W.S.J.; formal analysis, D.H.L., H.J. and K.C.M.; investigation, W.S.J., D.H.L., C.S.L. and K.C.M.; methodology, D.H.L., H.J. and K.C.M.; project administration, W.S.J.; supervision, W.S.J.; writing—original draft, D.H.L. and H.J.; writing—review and editing, W.S.J. and C.S.L. All authors have read and agreed to the published version of the manuscript.

Funding: This study was supported by a grant from the Korea Health Technology R\&D Project, through the Korea Health Industry Development Institute (KHIDI), funded by the Ministry of Health and Welfare, Republic of Korea (grant number, HR20C0021), and by the National Research Foundation of Korea (NRF) grant funded by the Korean government (MEST) (No. 2020R1A2C101176511).

Institutional Review Board Statement: The study was conducted in accordance with the guidelines of the Declaration of Helsinki and approved by the Institutional Review Board of Korea University Guro Hospital (2020GR0512).

Informed Consent Statement: Patient consent was waived by the Institutional Review Board of Korea University Guro Hospital, as the identities of the subjects were completely anonymous and there was minimal risk involved in the study.

Data Availability Statement: Data are contained within the article.

Conflicts of Interest: The authors declare no conflict of interest.

\section{References}

1. Pfaller, M.A.; Diekema, D.J.; Jones, R.N.; Sader, H.S.; Fluit, A.C.; Hollis, R.J.; Messer, S.A. International surveillance of bloodstream infections due to Candida species: Frequency of occurrence and in vitro susceptibilities to fluconazole, ravuconazole, and 
voriconazole of isolates collected from 1997 through 1999 in the SENTRY antimicrobial surveillance program. J. Clin. Microbiol. 2001, 39, 3254-3259. [CrossRef]

2. Kullberg, B.J.; Arendrup, M.C. Invasive Candidiasis. N. Engl. J. Med. 2015, 373, 1445-1456. [CrossRef]

3. Zeng, Z.R.; Tian, G.; Ding, Y.H.; Yang, K.; Liu, J.B.; Deng, J. Surveillance study of the prevalence, species distribution, antifungal susceptibility, risk factors and mortality of invasive candidiasis in a tertiary teaching hospital in Southwest China. BMC Infect. Dis. 2019, 19, 939. [CrossRef] [PubMed]

4. $\quad$ Kibbler, C.C.; Seaton, S.; Barnes, R.A.; Gransden, W.R.; Holliman, R.E.; Johnson, E.M.; Perry, J.D.; Sullivan, D.J.; Wilson, J.A. Management and outcome of bloodstream infections due to Candida species in England and Wales. J. Hosp. Infect. 2003, 54, 18-24. [CrossRef]

5. Kami, M.; Machida, U.; Okuzumi, K.; Matsumura, T.; Mori Si, S.; Hori, A.; Kashima, T.; Kanda, Y.; Takaue, Y.; Sakamaki, H.; et al Effect of fluconazole prophylaxis on fungal blood cultures: An autopsy-based study involving 720 patients with haematological malignancy. Br. J. Haematol. 2002, 117, 40-46. [CrossRef] [PubMed]

6. Berenguer, J.; Buck, M.; Witebsky, F.; Stock, F.; Pizzo, P.A.; Walsh, T.J. Lysis-centrifugation blood cultures in the detection of tissue-proven invasive candidiasis. Disseminated versus single-organ infection. Diagn. Microbiol. Infect. Dis. 1993, 17, 103-109. [CrossRef]

7. Morris, A.J.; Byrne, T.C.; Madden, J.F.; Reller, L.B. Duration of incubation of fungal cultures. J. Clin. Microbiol. 1996, 34, $1583-1585$. [CrossRef]

8. Wahyuningsih, R.; Freisleben, H.J.; Sonntag, H.G.; Schnitzler, P. Simple and rapid detection of Candida albicans DNA in serum by PCR for diagnosis of invasive candidiasis. J. Clin. Microbiol. 2000, 38, 3016-3021. [CrossRef]

9. Lefort, A.; Chartier, L.; Sendid, B.; Wolff, M.; Mainardi, J.L.; Podglajen, I.; Desnos-Ollivier, M.; Fontanet, A.; Bretagne, S.; Lortholary, O. Diagnosis, management and outcome of Candida endocarditis. Clin. Microbiol. Infect. 2012, 18, E99-E109. [CrossRef]

10. Nguyen, M.H.; Wissel, M.C.; Shields, R.K.; Salomoni, M.A.; Hao, B.; Press, E.G.; Shields, R.M.; Cheng, S.; Mitsani, D.; Vadnerkar, A.; et al. Performance of Candida real-time polymerase chain reaction, $\beta$-D-glucan assay, and blood cultures in the diagnosis of invasive candidiasis. Clin. Infect. Dis. 2012, 54, 1240-1248. [CrossRef]

11. Wang, K.; Luo, Y.; Zhang, W.; Xie, S.; Yan, P.; Liu, Y.; Li, Y.; Ma, X.; Xiao, K.; Fu, H.; et al. Diagnostic value of Candida mannan antigen and anti-mannan IgG and IgM antibodies for Candida infection. Mycoses 2020, 63, 181-188. [CrossRef]

12. Mikulska, M.; Calandra, T.; Sanguinetti, M.; Poulain, D.; Viscoli, C. The use of mannan antigen and anti-mannan antibodies in the diagnosis of invasive candidiasis: Recommendations from the Third European Conference on Infections in Leukemia. Crit. Care 2010, 14, R222. [CrossRef]

13. Inácio, J.; Flores, O.; Spencer-Martins, I. Efficient identification of clinically relevant Candida yeast species by use of an assay combining panfungal loop-mediated isothermal DNA amplification with hybridization to species-specific oligonucleotide probes. J. Clin. Microbiol. 2008, 46, 713-720. [CrossRef]

14. Widjojoatmodjo, M.N.; Borst, A.; Schukkink, R.A.; Box, A.T.; Tacken, N.M.; Van Gemen, B.; Verhoef, J.; Top, B.; Fluit, A.C. Nucleic acid sequence-based amplification (NASBA) detection of medically important Candida species. J. Microbiol. Methods 1999, 38, 81-90. [CrossRef]

15. Zhou, X.; Kong, F.; Sorrell, T.C.; Wang, H.; Duan, Y.; Chen, S.C. Practical method for detection and identification of Candida, Aspergillus, and Scedosporium spp. by use of rolling-circle amplification. J. Clin. Microbiol. 2008, 46, 2423-2427. [CrossRef] [PubMed]

16. Fallahi, S.; Babaei, M.; Rostami, A.; Mirahmadi, H.; Arab-Mazar, Z.; Sepahvand, A. Diagnosis of Candida albicans: Conventional diagnostic methods compared to the loop-mediated isothermal amplification (LAMP) assay. Arch. Microbiol. 2020, 202, $275-282$. [CrossRef] [PubMed]

17. Ou, H.; Wang, Y.; Gao, J.; Bai, J.; Zhang, Q.; Shi, L.; Wang, X.; Wang, C. Rapid detection of Salmonella based on loop-mediated isothermal amplification. Ann. Palliat. Med. 2021, 10, 6850-6858. [CrossRef] [PubMed]

18. Notomi, T.; Okayama, H.; Masubuchi, H.; Yonekawa, T.; Watanabe, K.; Amino, N.; Hase, T. Loop-mediated isothermal amplification of DNA. Nucleic Acids Res. 2000, 28, E63. [CrossRef]

19. Woźniakowski, G.; Kozdruń, W.; Samorek-Salamonowicz, E. Loop-mediated isothermal amplification for the detection of goose circovirus. Virol. J. 2012, 9, 110. [CrossRef] [PubMed]

20. Fredricks, D.N.; Smith, C.; Meier, A. Comparison of six DNA extraction methods for recovery of fungal DNA as assessed by quantitative PCR. J. Clin. Microbiol. 2005, 43, 5122-5128. [CrossRef]

21. McCulloch, E.; Ramage, G.; Jones, B.; Warn, P.; Kirkpatrick, W.R.; Patterson, T.F.; Williams, C. Don't throw your blood clots away: Use of blood clot may improve sensitivity of PCR diagnosis in invasive aspergillosis. J. Clin. Pathol. 2009, 62, 539-541. [CrossRef] [PubMed]

22. Springer, J.; Morton, C.O.; Perry, M.; Heinz, W.J.; Paholcsek, M.; Alzheimer, M.; Rogers, T.R.; Barnes, R.A.; Einsele, H.; Loeffler, J.; et al. Multicenter comparison of serum and whole-blood specimens for detection of Aspergillus DNA in high-risk hematological patients. J. Clin. Microbiol. 2013, 51, 1445-1450. [CrossRef] [PubMed]

23. Karakousis, A.; Tan, L.; Ellis, D.; Alexiou, H.; Wormald, P.J. An assessment of the efficiency of fungal DNA extraction methods for maximizing the detection of medically important fungi using PCR. J. Microbiol. Methods 2006, 65, 38-48. [CrossRef] [PubMed]

24. Vingataramin, L.; Frost, E.H. A single protocol for extraction of gDNA from bacteria and yeast. BioTechniques 2015, 58, 120-125. [CrossRef] 
25. Haugland, R.A.; Brinkman, N.; Vesper, S.J. Evaluation of rapid DNA extraction methods for the quantitative detection of fungi using real-time PCR analysis. J. Microbiol. Methods 2002, 50, 319-323. [CrossRef]

26. Avni, T.; Leibovici, L.; Paul, M. PCR diagnosis of invasive candidiasis: Systematic review and meta-analysis. J. Clin. Microbiol. 2011, 49, 665-670. [CrossRef]

27. Menu, E.; Landier, J.; Prudent, E.; Ranque, S.; L'Ollivier, C. Evaluation of 11 DNA Automated Extraction Protocols for the Detection of the 5 Mains Candida Species from Artificially Spiked Blood. J. Fungi 2021, 7, 228. [CrossRef]

28. Brinkman, N.E.; Haugland, R.A.; Wymer, L.J.; Byappanahalli, M.; Whitman, R.L.; Vesper, S.J. Evaluation of a rapid, quantitative real-time PCR method for enumeration of pathogenic Candida cells in water. Appl. Environ. Microbiol. 2003, 69, $1775-1782$. [CrossRef]

29. Lima, A.; Widen, R.; Vestal, G.; Uy, D.; Silbert, S. A TaqMan Probe-Based Real-Time PCR Assay for the Rapid Identification of the Emerging Multidrug-Resistant Pathogen Candida auris on the BD Max System. J. Clin. Microbiol. 2019, 57. [CrossRef]

30. McCarty, T.P.; Pappas, P.G. Invasive Candidiasis. Infect. Dis. Clin. North Am. 2016, 30, 103-124. [CrossRef] [PubMed]

31. Chow, J.K.; Golan, Y.; Ruthazer, R.; Karchmer, A.W.; Carmeli, Y.; Lichtenberg, D.A.; Chawla, V.; Young, J.A.; Hadley, S. Risk factors for albicans and non-albicans candidemia in the intensive care unit. Crit. Care Med. 2008, 36, 1993-1998. [CrossRef]

32. Edmond, M.B.; Wallace, S.E.; McClish, D.K.; Pfaller, M.A.; Jones, R.N.; Wenzel, R.P. Nosocomial bloodstream infections in United States hospitals: A three-year analysis. Clin. Infect. Dis. 1999, 29, 239-244. [CrossRef]

33. Morrell, M.; Fraser, V.J.; Kollef, M.H. Delaying the empiric treatment of candida bloodstream infection until positive blood culture results are obtained: A potential risk factor for hospital mortality. Antimicrob. Agents Chemother. 2005, 49, 3640-3645. [CrossRef]

34. Toda, M.; Williams, S.R.; Berkow, E.L.; Farley, M.M.; Harrison, L.H.; Bonner, L.; Marceaux, K.M.; Hollick, R.; Zhang, A.Y.; Schaffner, W.; et al. Population-Based Active Surveillance for Culture-Confirmed Candidemia-Four Sites, United States, 2012 2016. MMWR. Surveill. Summ. 2019, 68, 1-15. [CrossRef]

35. Velegraki, A.; Kambouris, M.; Kostourou, A.; Chalevelakis, G.; Legakis, N.J. Rapid extraction of fungal DNA from clinical samples for PCR amplification. Med. Mycol. 1999, 37, 69-73. [CrossRef]

36. Griffiths, L.J.; Anyim, M.; Doffman, S.R.; Wilks, M.; Millar, M.R.; Agrawal, S.G. Comparison of DNA extraction methods for Aspergillus fumigatus using real-time PCR. J. Med. Microbiol. 2006, 55, 1187-1191. [CrossRef]

37. Glee, P.M.; Russell, P.J.; Welsch, J.A.; Pratt, J.C.; Cutler, J.E. Methods for DNA extraction from Candida albicans. Anal. Biochem. 1987, 164, 207-213. [CrossRef]

38. Panda, B.B.; Meher, A.S.; Hazra, R.K. Comparison between different methods of DNA isolation from dried blood spots for determination of malaria to determine specificity and cost effectiveness. J. Parasit. Dis. 2019, 43, 337-342. [CrossRef] [PubMed]

39. Sepp, R.; Szabó, I.; Uda, H.; Sakamoto, H. Rapid techniques for DNA extraction from routinely processed archival tissue for use in PCR. J. Clin. Pathol. 1994, 47, 318-323. [CrossRef] [PubMed]

40. Walsh, P.S.; Metzger, D.A.; Higuchi, R. Chelex 100 as a medium for simple extraction of DNA for PCR-based typing from forensic material. BioTechniques 1991, 10, 506-513. [CrossRef] [PubMed] 